\title{
The Signs of Old Fleet Street to the End of the Eighteenth Century
}

\section{F.G. Hilton Price Dir.S.A.}

To cite this article: F.G. Hilton Price Dir.S.A. (1895) The Signs of Old Fleet Street to the End of the Eighteenth Century, Archaeological Journal, 52:1, 348-391, DOI: 10.1080/00665983.1895.10852678

To link to this article: http://dx.doi.org/10.1080/00665983.1895.10852678

册 Published online: 16 Jul 2014.

Submit your article to this journal $₫$

Џll Article views: 2

Q View related articles 두 


\section{THE SIGNS OF OLD FLEET STREET TO THE END OF THE EIGHTEENTH CENTURY.'}

Bj F. G. HILTON PRICE, Dir.S.A.

Shop signs are of great antiquity: it is quite probable that they were employed by the great nations of ancient times to denote their trades, and to help the inhabitants of cities and towns to find out where such and such a commodity was to be obtained. We have no actual record of their being used by the old Egyptians or other peoples of the Eastern world ; but it is highly probable that the tradesmen of those times did employ them, and placed some sort of inscription over their doors to indicate what they dealt in.

The Greeks, however, no doubt did employ the signboard, as Larwood and Hotten, in their History of Signboards, give the following quotation from Athenæus: "He hung the well known sign in front of his house."

When we arrive at Roman times, there is ample evidence to prove that they were largely employed in all their towns. The same authors state that in Rome some of the streets derived their names from some particular sign, such as vicus Ursi Pileati, the street of the "Bear with the hat on," their tavern sign the Bush, \&c. In Herculaneum and Pompeii several signs have been found. They are well painted and executed. Four of them are figured on Plate I. of Larwood and Hotten: a mule driving a mill, the sign of a baker; a goat, the sign of a dairy ; a cupid with a shoe on its head and one in its hand, as the sign of a shoemaker; and two men carrying a wire jar slung upon a pole, as the sign of a tavern. Many others could be enumerated, but these are sufficient to prove the great antiquity of the custom.

In London we may suppose that signs have been in use from the earliest periods. We have ample records of them in the fifteenth century, although principally those of taverns and booksellers. Later on every house had its sign, hanging from wooden brackets or iron rods and

\footnotetext{
1 Read at the Monthly Meeting of the Institute, November 6th, 1895.
} 
ornamental brackets, fixed into the walls of the houses. Some were swung across the streets, whilst others were affixed to posts on the sides of the streets or roads.

Charles the First granted a charter to the inhabitants of London making it lawful for them to expose and hang their signs over the streets, ways, and alleys of the said city, affixed to their houses and shops for the better finding out of such citizens' dwellings.

It must be rememberer in those days few people could read, and the masses were ignorant, and the picture sign was necessary to guide them to the house they wished for. Before the Great Fire of London in 1666, the streets were narrow, and the pent houses, with their signs swinging in the wind, must have made the houses very dark, and the noise of the signs swinging on their rusty hinges was considerable. Originally it was no doubt intended that the signs should express the trade or occupation of the owner to a certain extent; and in the early days, when a son was brought up to the trade of his father, they were appropriate; iut later, in the seventeenth century, the signs often remained the same, and the occupants changed about. Thus the original sign had lost its former significance, and they no longer served to indicate the trade carried on within.

Addison, writing to the Spectator, says : "I would enjoin every shopkeeper to make use of a sign which bears some affinity to the wares in which he deals. A cook should not live at The Boot, nor a shoemaker at the Roasted Pig; and yet, for want of this regulation, I have seen a goat set up before the door of a perfumer, and The French Fing's Head at a sword cutler's." Things changed in the days of Charles the Second, the people becoming more educated. Most of them could read an inscription, so the picture sign was not of much use. But they had become a great nuisance and a danger by reason of their occasionally falling upon the passers-by. One memorable sign in the parish of St. Bride's, Fleet Street, was so heavy and large that it actually pulled the front of the house out and killed four people. Consequently, an Act was passed, in the seventh year of his reign, to the effect that no signboard should hang across the streets, but that the signs should be fixed to the balconies or sides of the houses. 
After the Great Fire many of the signs were made of stone and built into the fronts of the houses, whilst the majority of people hung them over the doors or fixed them to the fronts of the houses as before. But in the eighteenth century they became as great a nuisance as they had been in the days of Charles the Second.

Thus, in the year 1762, the painted signs (many of which are said to have been painted by sign painters who dwelt in Harp Alley, or Harper's Alley, Shoe Lane, and others) were taken down by Act of Parliament, and only those of stone which were built into the fronts of the houses were suffered to remain, and these have from time to time disappeared as and when the said houses have been demolished, and at the present day very few of them exist in situ, and a very small number are preserved in the Museum of the Corporation of London, at the Guildhall. For a full description of these I would refer you to the excellent work on London Signs and Signboards by my friend Philip Norman, who has long worked upon this subject with great perseverance and ability.

It is much to be regretted that none of these picture signs were preserved, as many may have been of considerable merit, and most of them would be extremely interesting now.

In March of this year Bonnell Thornton got up an exhibition at his rooms in Bow Street of signboards, as a burlesque upon the exhibition of the Society of Artists. A catalogue was printed, which is to be seen in the Appendix of Larwood and Hotten's The History of Signboards. It is recorded that Hogarth, who enjoyed the joke, helped in the matter. It was a happy idea, as this was the year when they were taken down from the houses and the houses were numbered for the first time.

At first this change caused great annoyance to the inhabitants, as, the streets then being badly lighted, there was considerable difficulty in finding the shops; and it is said that many resorted to hanging up lanthorns, or placing candles on the balconies, or by painting their door posts, doors, or fronts of their houses some glaring colour, which signs were duly advertised in the newspapers in order to assist purchasers to the houses.

We may often observe in adpertisements in newspapers, 
advertising some quack medicine, that the particular house is to be known by a red or a green lamp burning over the door.

It is not my intention to enter into any minute explanation of the actual signs or the meaning of them, as that has been already so ably done by Messrs. Larrood and Hotten and P. Norman.

In making this collection of signs I have consulted almost every known London newspaper and all available contemporary literature.

The subject I have selected for my paper this afternoon is upon the Signs of Old Fleet Street. Notwithstanding I have been collecting the names of London signs for many years, and have a large collection of them, still I must crave your indulgence if I fail to make it as interesting as you may have expected in consequence of the short notice I have had from my friend Mr. Lyell, your excellent secretary.

As Fleet Street is a very long one, containing originally upwards of 200 houses, I propose first of all to deal with those signs which I can approximately, if not actually, give the present numbering, commencing with Temple Bar on the south side, then those located near the Middle and Inner Temple Gates, those described as being over against St. Dunstan's Church, Fetter Lane by Water Lane, Salisbury Court, Fleet Bridge, then up the north side of Fleet Street to Temple Bar.

This is a list of 315 signs, of which I have been able to localise but 65 to the present numbering. Then there are many others approximately localised; that is to say, we know their position in the street, but are unable to fix the number.

You have doubtless observed what a tendency there has been of late years to revive the signs; and many elegant wrought iron brackets bearing signs may now be seen hanging from the fronts of shops in the streets. Perhaps they may again be over-done, and so, for the third time, become a nuisance, and the London County Council will have to step in to have them removed; but I hope not, as, if not too big, they are rery ornamental. Some of the old bankers have always retained their signs, which they keep within, and place a picture of it on their cheques. 
In the following account it will be noticed what a great number of booksellers' shops thronged into that part of Fleet Street, between Temple Bar and St. Dunstan's, in the seventeenth century.

Taverns and coffee-houses were likewise excessively numerous. particularly in the parish of St. Dunstan's : In 1631 there were 58, and in 1650-74. Most of them were approached by long passages from the street to the house behind, as Dick's and the Rainbow are at the present day. All the courts in Fleet Street probably take their names from a tavern which formerly stood up the court or alley. Those would most likely be the most important taverns.

Coffee houses or taverns became so numerous in London and the country generally that King Charles the Second issued a Proclamation to suppress them in the fifteenth year of his reign (see London Gazette, December 27, December 30, 1675): "That the multitude of Coffee houses of late years set up and kept within this Kingdom, the Dominion of Wales and town of Berwick on Tweed, and the great resort of idle and disaffected persons to them, have produced very evil and dangerous effects, as well for that many tradesmen and others do therein mispend much of their time, which might and probably would otherwise be employed in and about their lawful callings and affairs ; but also, for that in such houses, and by occasions of the meetings of such persons therein, divers false, malitious and scandalous Reports are devised and spread abroad to the Defamation of His Majesties Government, and to the disturbance of the Peace and quiet of the realm; His $\mathrm{Ma}$ jesty hath thought fit and necessary, that the said coffee houses be for the future Put down and suppressed, \&c."

So now, as Dr. Samuel Johnson was wont to say, "Let us take a walk down Fleet Street."

In the year 1493 we read that Richard Pynson emprented at the Temple Barre of London.

At this time Temple Bar was, as doubtless you are all aware, a structure of wood; and it was not until after the Fire of London that a stone Temple Bar, which we all remember, was constructed for the most part of stones taken from older city buildings. It was completed in 1672 .

From 15571-1590, William How, printer and bookseller, 
dwelt there. In $1578 \mathrm{~W}$ ard and Mundee, booksellers, were likewise over Temple Bar.

In 1663 we find, from Noble's Memorials of Temple Bar, that at Munday's Coffee House, over Temple Bar, Dr. Bates held his conventicle. He had been a vicar of St. Dunstan's, and was turned out.

No. 1, The Marygold. In 1619 this house was a tavern kept by one Richard Crompton, who was " presented at the wardmote inquest for disturbing the quiett of John Clarke and his family being next neighbours, late in the nights from tyme to tyme by illdisorder." Shortly after this the Marygold was taken by William Wheeler, a goldsmith; then by Thomas Blanchard, who were the predecessors of Blanchard and Child. Ever since this time the same business has continued, and is still flourishing, under the style of Nessrs. Child and Co., who possess the original sign, which is hung up in their front shop. Up to and after the year 1670 the entrance to the house was under the foot arch of the Bar itself. Consequently, the names of Blanchard and Child do not appear in Fleet Street until after that date, as the entrance was in the parish of St. Clement's Danes. I have several instances of the house being described in 1664 as the Marygold and Sun

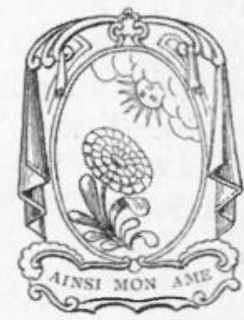
Without Temple Bar. When Temple Bar was taken down the entrance under the Bar was clearly seen. In the Poll Tax Book of 1660, which Mr. Tisley, the vestry clerk of St. Dunstan's, kindly allowed me to have a copy of, it showed that the site of No. 1, The Marygold, was then occupied by a goldsmith of the name of Thomas East. Thomas Blanchard was there in 1673 , and shortly after the house was altered and the entrance was in Fleet Street, as in the year 1677 we find Blanchard and Child were at The Marygold in Fleet Street keeping running cashes, so they must have taken in East's shop, who migrated into the Strand.

In a will of John Wavnewright, in 1625 , it is called the Man in the Moone, formerly a tarern called the Marygould, in the parish of St. Dunstan's in the IVest.

Between No. 1 and 2 was a passage, at the end of which 
was a tavern called the Sugar Loaf and Green Lattice. The following title on a book tells us that a printer once occupied the premises: "A Night's Search, by Humphry Mill, London, printed by Richard Bishop, for Laurence Blaicklock at the Sugar Loaf, next Temple barre."

Pepys writes on March 10, 1669: "Mr. Burges, we by water to Whitehall, where I made a little stop: and so with them by coach to Temple Bar, where at the Sugar Loaf, we dined, and then comes a companion of theirs, Colonel Vernon, I think they called him, a merry good fellow, and one that was very plain in cursing the Duke of Buckingham, and discoursing of his designs to ruin us, and that ruin must follow his counsels, and that we are an undone people."

1691, John May was here.

1697, and a few years on, William Biggins, and Dorothy Biggins his wife, was the landlord.

Early in the eighteenth century this house was embodied in Child's Bank.

No. 2 was the King's Arms and Civet Cat. "Mr. Shenstone lodged at the King's Arms at Mr. Wintles a perfumers." From 1711-1728 Henry Gilbert, hatter, was here.

1728, the Craftsman of March 1, 1728-9, announces " that Benjamin Tassel, haberdasher and hosier, continues the shop of Henry Gilbert, haberdasher of hats, lately deceased, next the Old Devil Tavern within Temple Bar; where his customers and others may depend upon being faithfully served and to their satisfaction."

A hosier was still there in $\mathbf{1 7 6 6 .}$

It afterwards became the shop of Mr. Knowlton, a hatter, who was succeeded by John Preedy, and whose son, John Knowlton Preedy, remained there until the house was pulled down in 1879, when the site was included in Child's Bank.

Next to this was a passage leading up to the Devil Tavern, between No. 2 and 3 . It was sometimes called St. Dunstans or the old Devil Tavern. This famous old house was mentioned as early as 1563 , and was much frequented by the quality in the days of James the First. Simon Wadlow was then the vintner. Ben Jonson used the house, 
and wrote many of his verses under the influence of the wine he drank at the Devil.

It has been frequently mentioned by Pepys in his Diary, and by a host of other writers.

The following notice appeared in the Daily Advertiser, February 23, 1742: "The gentlemen educated at the Rev. Mr. Cox's School at Kensington are desired to meet at the Golden Lyon (which was opposite Fetter lane) and Devil Tavern near Temple Bar to-morrow the 24th instant. Note.-Dinner will be on the table at 3 o'clock."

There was a large room here called the Apolio, in which great entertainments took place. Ben Jonson wrote the rules in Latin, also a welcome, which was painted in letters of gold on a black board, placed near a bust of Apollo. These latter are now in the possession of Messrs. Child and Co. It runs thus :
Welcome all who lead or follow
To the oracle of Apollo-
Here he speaks out of his pottle,
Or the tripos, his Tower botrle;
All his answers are divine,
Truth itself doth flow in wine.
Hang up all the poor hop.drinkers,
Cries old Sim, the King of Skinkers ;
He who the half of life abuses,
That sits watering with the Muses,
Those dull girls no good can mean us ;
Wine it is the milk of Venus,
And the poets' horse accounted:
Ply it, and you all are mounted.
'T'is the true Phœbian liquor;
Cheers the brains, makes wit the quicker,
Pays all debts, cures all diseases,
And at once three senses pleases.
Welcome all who lead or follow
To the oracle of Apollo.

Beneath it is written "O rare Ben Jonson." Sim, the King of Skinkers, was Simon Wadlow, the host in these days.

The Devil Tavern fell into decay, and Messrs. Child and Co. purchased the freehold of these premises in 1787 , when they pulled down the old house and erected a row of houses lately known as Childs Place on the site, which in their turn were demolished in 1879 to make way for the new banking house. The old cellar of the Devil was then 
destroyed. Buried deep in sawdust a bottle of wine was found, and some empty ones. It probably contains port wine. The bottle is now in my possession.

Among the many curious events that took place here, I will read you the following, which happened in the days of George II. :-

"The late facetious Duke of Montagu (the memorable author of the bottle conjurer at the little theatre in the Haymarket) gave an entertainment at the Devil Tavern, Temple Bar, to several nobility and gentry; selecting the most conrivial, and a few hard drinkers who were all in the plot.

"Heidegger was invited, and in a few hours after dinner was made so dead drunk that he was carried out of the room and laid insensible upon a bed. A profound sleep ensued; when the late Mrs. Salmon's daughter (from the Golden Salmon, the keeper of the waxworks) was introduced, who took a mould from his face in plaster of Paris. Upon this, a mask was made and coloured to the most exact resemblance, and a few days before the next masquerade (at which the King promised to be present with the Countess of Yarmouth) the duke made application to Heidegger's valet de chambre and bribed him to discover what suit of clothes he was to wear, and then procuring a similar dress, and a person of the same stature, he gave him his instructions.

"On the evening of the masquerade, as soon as $\mathrm{His}$ Majesty ${ }^{1}$ was seated (who was always known by the conductor of the entertainment and the officers of the Court, though concealed by his dress from the company), Heidegger, as usual, ordered the music to play 'God save the King'; but his back was no sooner turned than the false Heidegger ordered them to strike up 'Over the water to Charley.' The whole company were instantly thunderstruck, and all the courtiers not in the plot were thrown into a stupid consternation.

"Heidegger flew to the music-gallery, swore, stamped, raved, accused the musicians of drunkenness, or of being set on by some secret enemy to ruin him. The King and Countess laughed so immoderately that they hazarded a discovery. 
"While Heidegger remained in the gallery "God save the King' was the tune; but when, after setting matters to rights, he retired to one of the dancing rooms to observe decorum was kept by the company, the counterfeit, stepping forward and placing himself upon the floor of the theatre just in front of the music-gallery, called out in a most audible voice, imitating Heidegger, ' $D--d$ ' them for blockheads, adding, had he not just told them to play 'Charley over the Water'? A pause ensued. The musicians, who knew his character, in their turn thought him either drunk or mad; but as he continued his vociferation, 'Charley' was struck up again. At this repetition of the supposed affront, some of the officers of the Guard, who always attended upon these occasions, were for ascending the gallery and kicking the musicians out; but the Duke of Cumberland, who cuuld hardly contain himself (His Royal Highness, too, being in the secret), interposed.

"The company were thrown into the greatest confusion. Shame! shame! resounded from all parts, and Heidegger once more flew, in a violent rage, to that part of the theatre facing the gallery.

"Here the mischievous Duke of Montagu, artfully addressing himself to him, pretended that the King was in a violent passion; and that his best way was to go instantly and make an apoiogy, for certainly the musicians were mad, and afterwards to discharge them. Almost at the same moment he ordered the counterfeit Heidegger to do the same. The scene now became truly comic in the circle before the King. Heidegger had no sooner uttered an apology for the insolence of his musicians than the false Heidegger advanced, and, in a plaintive tone, exclaimed, 'Indeed, Sire, it was not my fault, but that the devil's in my likeness,' pointing to the true Heidegger, who turned round, staggered, grew pale, and was speechless.

"The Duke of IIontagu, thinking the hoax had taken a serious turn, now humanely whispered in his ear the sum of the plot, and the counterfeit was ordered to take off his mask. Here ended the frolic, but. Heidegger swore he would never attend any public amusement again unless that witch, the waxwork woman, was made to break the mould and melt down the mask before his face." 
[Extracted from the Reminiscences of $H$. Angelo, 1828-30.] There was another account of it in the Public Advertiser of November $9,1779$.

No. 3 or 4 was the Mitre, described as being between Temple Bar and the Middle Temple Gate. From 1660 to 1681 we find that John Starkey, a bookseller, kept shop here. He published Shadwell's Plays; he afterwards printed a book against the Government, and was exiled to Amsterdam.

In 1692 we find Abel Roper, a bookseller, was here.

No. 7, Hand and Star, between the two Temple Gates. 1553-1597, Richard Tottell or Tothill, a bookseller, was here ; in 1578 he was Master of the Stationers' Company, and was in business over forty years. 1594, Charles Yetsweirt, bookseller, and afterwards the widow, Jane Yetsweirt, had a press here. 1660, Gabryell Bradle, a stationer, was here ; from 1691-94 Thomas Bever, a bookseller and stationer. In 1710 we find the name of Mr. Plaistow; 1730-1741, Joel Stephens, law stationer. From 1818 to the present time it has been in the hands of the Butterworths, law booksellers.

No. 8, Young Devil, which tavern appears to have been started about 1689, in opposition to the Old Devil and St. Dunstan. In this year Robert Fenwick appears to have been mine host; he sold tickets for the annual feast of the sons of the Clergy to be kept at Merchant Taylor's Hall. The Society of Antiquaries met here on January 9, 1707-8, and for some time afterwards. It was originated about this time by Mr. Wanley, the goldsmith, and Le Neve. The entrance was down a flight of steps; consequently, the tavern was below ground.

Richard's Coffee House, or Dick's as it was afterwards called and is now, was approached by a long passage. It was called Richard's after its landlord, Richard Torver. It was founded about 1680 . Timms says that this house was originally the printing office of Richard Tottell, who lived at the Hand and Star next door.

The Crown was probably No. 9, situated between the two Temple Gates. From 1652-1674 William Leak, a bookseller, was there ; in 1660 he advertised the Ident in four books. From 1685-1694 John Weld was there; and in 1695 a Mr. Fowler. It is possible this house had 
another sign after this, as I do not find it mentioned again.

No. 11, The Black Lyon, between the two Temple Gates. The first occupier I know of was John Grone, a stationer, who was there in 1660 . The London Gazette, July 12, 1669, has the following: "These are to give Notice that the receipt for Letters within the Temple Barre, is removed from Mr. Eales and for the more secure conveyance of Letters to the General Post office is now settled with Mr. Grone, stationer at the Black Horse, between the two Temple Gates within the Barre." July 19, 1669, this was corrected to Black Lyon. In 1677 we find it had become a goldsmith's shop, inhabited by Thomas Fowles. It eventually became Mead and Co., and they failed in 1727. In 1735 it was tenanted by Arthur Mydleton, a glover; then Eyres' original mineral water warehouse; and in 1760 that business was carried on by W. Owen, who was likewise a bookseller.

No. 14, The Sun, next the Rainbow. Here, between 1652-1675, Abel Roper, John Martyn, and Henry Herringman published Dugdale's Baronage of England; from 1683 to 1699 William Rogers, bookseller, was here; he published $A$ Collection for the Improvement of IIusbandry and Trade. In 1706, Ferrers, an upholsterer; 1718, R. Francklin, a bookseller; 1731, I. Shuckburgh, a bookseller.

No. 15, The Rainbow. In 1636 Ephraim Dawson, a bookseller, kept shop here ; 1641-1651, Daniel Pakeman, probably a bookseller, but in the latter year he advertised for a "gray nagge" that was lost. In 1657 James Farr was, at a wardmote, presented "for making and selling of a drinke called coffee, whereby in making the same he annoyeth his neighbours by evill smells; and for keeping of fire for the most part of the night and day, whereby his chimney and chamber hath been set on fire, to the great danger and affrightment of his neighbours." In 1660 he was described as a barber chirugion of the Livery. In 1666 he issued a halfpenny token (see Boyne), and books were printed here at this time for Samuel Speed. This was the second coffee house that was established in London, and became very fashionable at the end of the seventeenth century and beginning of the eighteenth century. The 
following appeared in The Newes," October 15,1663: "True Sympatheticall Powder curing all green wound, and infallibly Toothache, is sold by Samuel Speed, Bookseller at the Rainbow, price of each paper is four shillings." Speed was also a stationer, and is supposed to have been the first to sell coffee. The old house was pulled down in 1860 , and the new and present Rainbow erected, which is still a tavern.

No. 16, Cross Keys and Cushion, next to Nandos between the Temple Gates. It was probably this house. From 1685 to 1688 Sedgwick, a goldsmith, was here. In 1704-1728 Bernard Lintot, the bookseller, lived here, who published for Alexander Pope, Colley Cibber, and Gray. In 1709 he advertised some of Shakespeare's works, riz., "Venus and Adonis," "The Rape of Lucrece," \&c. In 1715 , June 23 , he announced the publication in the London Gazette: The first four books of the Iliad of Homer, Translated by Mr. Pope, who has added a critical Preface, an essay on the Life, Writings, and Learning of Homer, and large notes to each Book \& c. Printed in Folio for Bernard Lintot between the Two Temple Gates, who has obrained a grant from his Majesty King George for the sole Printing and Publishing thereof, Price stitched $12 s$. or $14 s$. bound. N.B. A small number are printed on large Faper Price a guinea stitched or 25s. bound." In 1736 Henry Lintot was here, and from 1744-1761 Charles Bathurst, bookseller.

No. 17, Nandos, a coffee house about 1707, east corner of Inner Temple Lane. It was a favourite resort in the eighteenth century, in consequence of the fame of its punch and the charms of its landlady. This house, inscribed formerly the Palace of Henry VIII and Cardinal Wolsey, is erroneous, as it was in reality the office for the management of the estates of the Duchy of Cornwall for Henry, Prince of Wales, son of James I. The house was built in 1609 in plain Jacobean style. When Nandos came to an end this house was taken. about 1785 , by Mrs. Salmon for her waxwork exhibition, where it remained till 1812. It is now occupied by Mr. John Carter as hair cutting rooms.

No. 18 was probably the Golden Eagle, over against St. Dunstan's Church. From 1683-93 it was occupied by 
Abraham Chambers, a goldsmith. On April 28, 1693, he was attacked by eight highwaymen and was barbarously stabbed with a sword, of which he died that night.

No. 19, The Three Squirrels. About 1650 we find that Henry Pinkney, a goldsmith, was here; that he afterwards issued a farthing token from this house (see Boyne). $\mathrm{He}$ subsequently moved further eastwards, to the Golden Dragon, at which sign he was in 1660. William Pinckney was here at that same date, as is proved by the books of the parish. Jarnes Chambers, a goldsmith, kept running cashes here about 1680 , and remained some time, and the

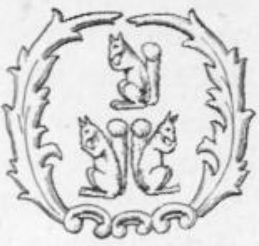
business was consecutively continued by various persons until it descended to the present firm of bankers, Messrs. Goslings and Sharpe.

No. 20 was probably the Wheatsheaf, as it is described near the Inner Temple Gate and opposite Serjeant's Inn. In 1660 the Poll tax shows me that Thomas Fitzer, a saddler, was living. next door to William Pinckney at the Three Squirrels; he was there until 1679. In 1737 we find a linen draper of the name of Gould there. These last three houses now form the banking house of Messrs. Goslings and Sharpe.

No. 21, This was probably the Three Daggers - in 1731-6 called the Three Daggers and Queen's Head. Francis Tyton, stationer of the Livery, was here from 1654-73. Thomas Wotton, bookseller, was here from 1688 to 1737 , and perhaps later. In 1705 he was described as a gold. smith as well.

Blue Ball, by Hercules Pillars Alley. In 1737 Mrs. Giles, a milliner, advertised pills for purif ing the blood.

No. 27 is the site of Hercules Pillars Tavern. Up the alley were many small taverns. In $1651 \mathrm{~J}$. Nuthall sold The Chysurgeons Directorie here; Robert Cole issued a halfpenny token from here in 1664-6 (see Borne). The tavern was in great repute in the seventeenth century, and Pepys frequently went there, and was mighty merry.

Next door was the Angel, perhaps No. 28. Here, in 1672, John Hancox, a grocer, kept his shop. It was some times called the Golden Angel; he issued a halfpenny token. In 1675 we find Charles Smith, a haberdasher; 
1684, William Hull, a stationer; and, in 1691, Thomas Warnford, a haberdasher.

No. 30 Addison's Head. C. Corbett, bookseller. in 1737, and his business was continued from father to son into the present century.

Black Boy, over against St. Dunstan's Church, probably near Falcon Court, and may be now No. 31, as I find from the Poll tax book that was the position for Abel Roper in 1660 , but his name is not again found till much later at this house. Grigge, a goldsmith, was also here. In 1663 Mrs. Seyle, a bookseller, was here. She sold lozenges for the cure of consumption. From 1676 to 1685 Christopher Wilkinson, a bookseller, kept shop here ; 1691-6, William Pate, a woollen draper, lived here. From 1709-14 we find the names of Arthur Collins, who in 1709 published the first edition of his Peeragre; he was called by Harley "a broken bookseller." Abel Roper was here at this time, and printed the newspaper called the Post Boy from this sign. In 1719 it was occupied by Mr. Huxley, a hatter. The Ship, next Falcon Court, in 1661 was occupied by William Denton, and 1756 by William Sandby, a successful bookseller, who afterwards became a partner in the banking house of Messrs. Snow \& Co. in the Strand.

No. 32, The Falcon Tavern, on the site of No. 32. 1685, Mrs. Coles.

Falcon, or Golden Falcon as it was sometimes called, was occupied by a printer named William Griffith from 15561571; he sold his books at the Griffin, a little above the Conduit. In 1572-1587 Henry Middleton succeeded him as a bookseller. From 1679-1689 Thomas Minshull, a goldsmith, was here.

No. 32, The Crown. This is the same house as The Ship, re-named. Soon after Sandby gave up the bookselling trade he sold the goodwill to John McMurray of the Royal Navy. In 1768 he dropped the Mac, and became John Murray, establishing the famous business which afterwards migrated to Albemarle Street. In a list of the London Bankers, in The Daily Jou'nal or, the Gentleman's and Tradesman's complete Annual Accorrpt Book for 1768, we find the name of John Murray at The Croun in Fleet Street. He died in 1793, and his son left Fleet Street in 1812 for Albemarle Street, where the firm still flourishes. 
Golden Dragon, near the Inner Temple Gate, judging from the position the name of Henry Pinkney, the goldsmith, takes in the Poll tax book, as being some doors east of Hercules Pillars, I think it might possibly be No. 34, but it is uncertain. He was sometimes called Major Pinkney, and was here about 1660 . He was a goldsmith of the Livery, and paid $£ 5$ Poll tax. Boyne says he issued a farthing token from the Three Squirrels. Pepys, on December 1, 1660, writes: "Mr. Shepley and I went into London and calling upon Mr. Pinckney the goldsmith, he took us to a taverne and gave us a pint of wine." The house was destroyed in the Great Fire of 1666.

In $1697 \mathrm{Mr}$. Perin, a mercer, advertised in the Post Boy, that he is intending to leave off his trade, hath several sorts of silks, stuffs and Bangalls to dispose of and the House and Shop is to let.

Bell and Dragon, in 1699, was the house of Robert Gower, an apothecary, who advertised Medicinal Spaw Water from Germany. Before the Great Fire it was known by the sign of The Three Cranes. The site is now occupied by Messrs. Hoare's Bank.

Three Flower de Luces was in the occupation of Millicent Huxley, widow, in 1727, and was on the site of Messrs. Hoare's Bank.

Golden Bush and Sun, 1727, in the hands of John Pemberton. This now forms part of Messrs. Hoare's Bank.

No. 37, The Golden Bottle. Since the year 1690 this house has been in the occupation of Messrs. Hoare \& Co., bankers. The sign originated in Cheapside, where $\mathrm{Mr}$. Hoare had been established many years, and moved here in October, 1690, bringing his old sign with him. I find, from the deeds kindly placed at my disposal by Messrs. Hoare, that this house was previously known by the sign of the Golden Hind, or Hynde, and from 1660 to 1677 it was in the possession of Messrs. John Mawson and

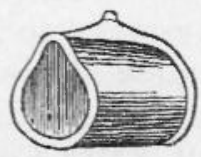
Co., who, the Little London Directory of 1677 record; were keeping running cashes at this sign. The banking premises now occupy the site of several houses, from 34 to 39 , including the famous Mitre Tavern and the Three Flower de Luces, Bell and Dragon, Golden Bush and Sun. 
No. 38, next door to the Mitre Tavern, was occupied by a bookseller of the name of J. Williams from 1768 to 1774 .

Between Nos. 38 and 39, Mitre Tavern. The old famous house of the time of Shakespeare and Ben Jonson stood at the back of this house. It was approached by a long passage called Cat and Fiddle Court, or Alley, which was probably the name of some tavern which had existed here in early days, of which all record is lost. This is the house in which "From the Fair Lavinian Shore. Shakespeare's Rime made by him at the Mytre in Fleete Streete," is said to have been written. The house was first mentioned in 1613, in the register of St. Dunstan's, when William Hewitt was buryed. This house was often visited by Pepys and others of this time.

The Council of the Society of Antiquaries were in the habit of dining here between 1728-1775 on St. George's Day. The Royal Society also patronised it. It was much frequented by authors, including Dr. Johnson, who usually supped here. The house ceased to exist as a tavern in 1788. when it became the premises of Macklin's Poets' Gallery, and, lastly, Saunders'Auction Rooms. It was then taken down. The site is now occupied by Messrs. Hoare, the bankers.

No. 44, Flower de Luce, described as being at the Corner of Mitre Court, so is probably the site of 44 . From 1672-1705 Charles Harper, a bookseller, kept shop here; and during part of the same time, 1694--1734, James Seamer or Seymour, a goldsmith, was here; in $1674 \mathrm{Mr}$. Williams, a hosier; and from 1723-9, J. Hooke, publisher.

Joe's Coffee House, afterwards called the Mitre Tavern, was in Mitre Court, and is still there. It was a favourite resort of Johnson and Boswell. The present house is very much altered since those times.

No. 45, Hole in the Wall Tavern, was on the east side of Mitre Court. It is here where the "Free and Easy Johns" were held, which was a society which met in this house to tipple porter and sing Bawdry. (Grose's Dictionary.)

No. 46, Johnson's Head, corner of Hare Court, formerly Ram Alley. 
In 1787 G. Kearsley, a bookseller, was here. This was a modern sign for an old house.

No. 47 or 52. Black Moor's Head and Golden Sugar Loaf, against Fetter Lane and within two houses of Serjeant's Inn, which would make the site of this house on No. 47 or 52 .

1709, John Brett, woollen draper.

1721, Mr. Playter, woollen draper.

1736, Joseph Brett, woollen draper.

1737 it was opened by Thomas Jemmitt, grocer, who advertised he sold coffee, tea, chocolate and grocery of all sorts, wholesale and retail, equal in goodness and as cheap as any other in the trade. Before he took this house it was known by the sign of Black Moors Head only.

No. 49 (?) The Talbot, against St. Dunstan's, Fetter Lane end. In 1653-1664 Charles Adams, a bookseller and stationer, was here. He paid poll tax in 1660. Adams advertised a powder called the Countess of Kent's powder, a veritable panacea. From 1683-1698 William Warter, bookseller and stationer, who sold curious packs of cards. In 1709 John Lenthall, stationer, who advertised in the Post Boy, November 6, 1712: "All the new pictur'd cards, curiously engraven on Copper Plates, following, viz : Fortune Telling Cards, which resolve by astrology their good and bad fortune, in Love, Marriage \&c. a Touch on the Times, Love Cards, Proverb Cards, Mathematical, Geographical and Arithmetical Cards, per 2s. each pack."

Amicable Assurance Society for the Insuring of Lives. This is supposed to have been the oldest insurance office in London. In the London Gazette, August 5, 1706, the following advertisement appeared :-

"These are to give notice, that a Court of the Directors of the Amicable Society for a Perpetual Assurance office (now incorporated by Her Majesties' Letters Patent under the Great Seal of England) was held at Mr. John Hartley's Bookseller, over against St. Dunstans Church in Fleet Street on the 30th July last: where the Directors and the Register being sworn for the due execution of their respective offices, according to the Directions of the Charter they have thought fit to order, that Policies shall begin and be continued to be 
delivered out on and after the 6th Instant at the said Mr. Hartley's where Proposals may be had, and attendance will be given from 10 to 12 before noon and from 3 to 6 after noon, Holidays only excepted. And all those that had subscribed to the said Society are desired to take out their Policies within one month at farthest after the said 6th Instant. The subscriptions are near compleated and it is determined after that time to admit of new Subscribers to the room of those that shall neglect to take out their Policies, according to the Subscription they have already made."

After having flourished for 160 years, its business was, in the year 1865, transferred to the Economic Life Assurance Co. Their house is now occupied by the Norwich Union Fire Office.

No. 53, The Golden Buck. In 1686 a goldsmith called Sommers was here, and Parker and Cradock, also goldsmiths, were at this sign in 1712. From 1709 Philip Overton, picture seller, and John Pemberton, bookseller, were here for many years. It was sometimes called the Golden Buck and Sun, and once I have seen it called the Roebuck. In 1711 The Cries of London, consisting of 74 copper plates, each figure drawn from the life by the famous M. Laron, etched and engraved by the best workmen. Each plate is printed on a half sheet of Demy paper for $10 \mathrm{~s}$. a set. In 1762 Robert Sayer continued the business, then Robert Laurie and James Whittle. $\Lambda$ large quantity of interesting and valuable engravings and prints were published here during the last and present century.

No. 56, The Green Dragon, a tavern, first mentioned in 1636. It was destroyed in the Great Fire, and rebuilt in 1667. It was frequently mentioned in the newspapers. It is now famous for its discussion Forum.

No. 60, Tycho Brake's Head. Here, in 1767, George Adams sold New Globes elegantly mounted and a great choice of Mathematical, Optical, Philosophical and Electrical Instruments.

No. 64, Bolt in Tun Inn. This was a very ancient hostelry, and is first mentioned in a grant to the White Friars in 1443 and in the Registers of St. Dunstan's 1629-1660. On September 2, 1665, a boy was found dead of the Plague in the Hay loft. 
In 1704 The Windsor Coach, horsed by Simon Gray and John Atlee, started from this inn, and in 1734 it was advertised in London Evening Post that the Abingdon Stage Coach is removed from the White Horse, in Wood Street, to the Bolt and Tun Inn, in Fleet Street, and sets out every Tuesday, Thursday, and Saturday. Performed (if God permit).

We read in Noble's Temple Bar that the host, Thomas Walker, in 1759 was "presented" for entertaining disorderly women, \&c. This house is now a Railway Parcels receiving office.

The Griffin, next door to the Bolt and Tun. From 1723-1728 Mr. Miles, a turner, was there.

No. 66, The Borr's Head Inn, by Water Lane, now Whitefriars Street. I first find this sign named in 1640 . William Healey, or Hayley, was here from 1664-1680, and in 1668 issued a halfpenny token. We next find, in 1775, Sarah Fortescue, a widow, at the Boars Head Ale House, was "presented" for keeping a disorderly house.

The house is still an inn.

No. 67, Black Lyon Inn, by Water Lane. It was kept by Mr. Walsh in 1676 . The sign of the house was changed in or about 1683 to the Dial and Three Crowns, and Thomas Tompion, the celebrated watchmaker, resided there. He was made free of the Clockmakers' Company September 4, 1671, elected on the Court of Assistants September 7, 1691, served the office of Warden 17001703, chosen Naster September 29, 1704. He was elected a Fellow of the Royal Society. He died November 20, 1713 , and was buried in Westminster Abbey. He was succeeded in his trade by George Graham, his nephew.

Tompion made a watch for Charies II. with a spiral balance or pendulum spring. One end of the spring was made fast to the arbor of the balance wheel, whilst the other was secured to the plate, and the oscillations were rendered equal and regular by its elastic force. $\mathrm{He}$ invented the cylinder escapement, with horizontal wheel, in 1695 .

George Graham likewise filled all the offices in the Clockmakers' Company, was a great horologist, and died in 1751, and was buried in Westminster Abbey. His 
descendant, Mr. Webster, carried on the business, which is now conducted at the Dial and Three Crouns in Queen Victoria Street.

The site of the house in Fleet Street is now the Daily News office.

No. 99, Croun and Sugar Loaf Tavern in 1815.

No. 101, Red Lion, near Fleet Bridge. John Hardham lived here and sold his celebrated No. 37 Snuff. He died in 1772.

No. 102, Mount Pleasant. Lockyer was its first tenant in 1719. It subsequently became a "Saloop" house, when coffee, sold for seven shillings a pound, was a luxury, and was the only place in London where the liquor made from Sassafras chips could be obtained. Lockyer died 1739. Thomas Read was the next tenant, and the house was afterwards known as liead's Coffee ITouse.

No. 112, The Popinjay.

No. 134 is the site of the Globe Tavern. It was mentioned as early as 1636 , and was rebuilt after the Fire. It became a very celebrated house, and was much frequented by famous people. In October, 1663, Pepys took Sir W. Batten there. It is frequently named in old newspapers up to the latter part of the eighteenth century. It was rebuilt after the Great Fire, and at one time was kept by Sir John Tash, Knight.

No. 138 (?) Astronomico-Musical Clock, between Bolt Court and Johnson's Court. Here, in 1731, lived Christopher Pinchbeck, the inventor of a metallic composition, called Pinchbeck. Toys and other articles were made of it. He died in 1732, and the business was carried on by his son until 1783, when he died. In 1775 his shop window was broken into and a watch was stolen in the day time. The thieves were caught.

No. 146, Wine Office.

No. 152, Orange Tree, opposite the Bolt and Tun. 1756, Staveley and Cross sold a collection of tree and shrub seeds from North America. John Mason, seedsman and net maker, carried on the business till 1793 .

No. 164, Horn in the Hoop Tavern. In 1386 we find that John Phippe, a "curreour," lived here. It was then called Le Horn on the Hope. The next we sarn about it 
was in 1405, when Thomas atte Hay, a goldsmith, left it to the Goldsmiths' Company for the better support and sustentation of the infirm members of the Company, and he desired to be buried in the Church of St. Peter de Westchepe.

A token was issued of this house. In 1597 it was called the Horne, also in 1772, and subsequently it has been known as Anderton's Iotel.

No. 169 is the site of the Red Lion Tavern. It was mentioned as early as 1592. In 1602 Ambrose Lupton, innholder at the Red Lyon in Fleet Street and by his freedome keepeth a cellar at the Red Lyon Gate, had no less than six cans and eleven pots seized for false measure. It was not heard of after 1666. Red Lion Court was named after it.

The site was occupied by the Three Angels in 1772 . when we find William George, a mercer, was there.

No. 17., Black Talbot, kept by Ralph Foster in 1657.

No. 173, Three Pigeons and Sceptre. In 1788 it was occupied by Thomas Smith and Co., India Muslin Warehouse, who were there for some years, and advertised the cheapness of their linen drapery.

No. 174 or 175, Ship, corner of Crane Court, near Fetter Lane. Charles Gretton, a celebrated watchmaker, lived there in 1686-1697.

John Curghey, a goldsmith, was there in 1734.

The Leg, a hosier's shop, was one side of Crane Court in 1724 -either No. 174 or 175 .

Nos. 177-178, Peele's Coffee House. It was in existence in 1718, as, by the London Gazette, we are informed that a London victualler being a bankrupt met his creditors there.

No. 184 (?) Spread Eagle, an old gabled house. In 1570 it was a baker's shop, kept by Henry Elsing. " It was pulled down in 1891 .

No. 189, The Salmon or Golden Salmon, the sign of Mrs. Salmon's wax-work shop, which was very celebrated for many years. The Spectator, No. 28, says: "It would

${ }^{1}$ Bradford, one of the most eminent of the Marian Martyrs, was taken at Mr. Elsing's house in 1553. (Fore.) 
have been ridiculous for the ingenious Mrs. Salmon to have lived at the sign of the Trout; for which 6. reason she has erected before her house the figure of a fish that is her name sake." The old house was pulled down about 1802 , it having been taken by Messrs. Praeds and Co., the bankers, who built a new one, and have recently vacated it. Mrs. Salmon then went opposite, to No. 17.

No. 192, Three Pidgeons, over

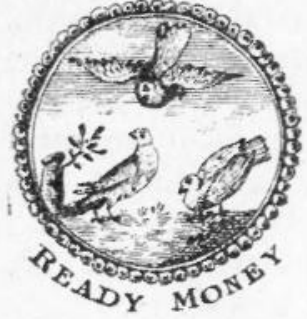

From the bill-head of Middleton and Innes, haberdashers. against the Inner Temple Gate. 1689-1700, John Newton, a bookseller, was there. In 1790 it was occupied by Middleton and Innes, haberdashers and linen drapers.

No. 192, Black Moor's Head. Here it is said Abraham Cowley, the poet, whose father was a grocer, was born. In 1740 we find it was tenanted by a grocer who sold fine tea. In 1787 the firm was North. Hoare, Nanson and Simpson, grocers. North soon retired and opened a new shop at 190 , to which subsequently all the business followed him, as did likewise the partners. Here they remained until recently.

King's Head Tavern, south-west corner of Chancery Lane in Fleet Street. This was an old five-storied house built of carved oak. This was a tavern as early as the days of Queen Elizabeth. The signboard and tokens showed a full-faced portrait of Henry VIII. The tavern occupied the first and second floors; the ground was let out in shops. It is said that Sir Joln Oldcastle's house occupied this site. He was executed by fire in 1417 in St. Giles' Fields. Richard Marriot, the bookseller, had a shop in 1665 and several years on, under this tavern. In 1653 Izaak Walton's Compleat Angler was thus advertised in the Mercurius Politicus of May 19 :-

"There is newly extant, a Book of $18^{\mathrm{d}}$. Price, called the Compleat Angler, or the Contemplative Man's Recreation, being a Discourse of Fish and Fishing, not unworthy the perusal of most anglers. Printed for Richard Marriot in St. Dunstans Churchyard." In another paper it stated it was written by Iz. Wa. 
To jace page 371 .

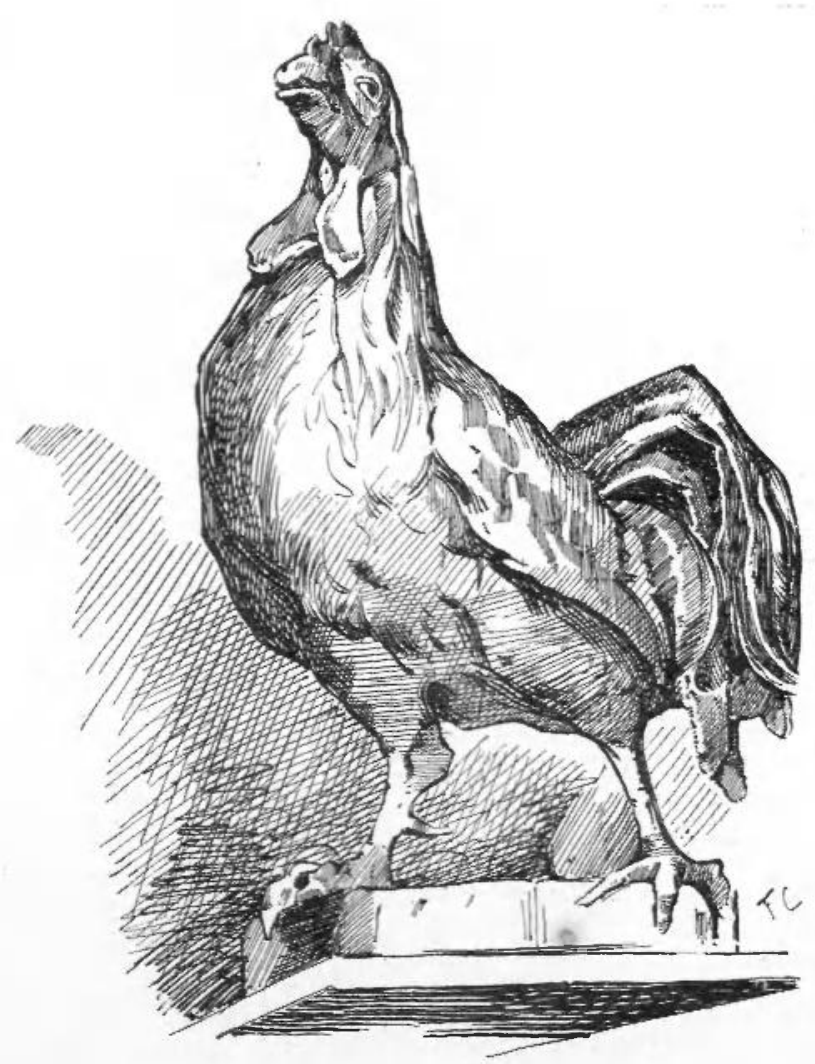

The Sign of "The Coce." 
The following curious advertisement appeared in the Mercurius Publicus Jan. 1 to 8, 1662, which seems to indicate he was Samuel Butler's publisher:-

"There is stolen abroad, a most false imperfect coppy of a Poem (called Hudibras) without name either of printer or bookseller, as fit for so lame and spurious imitation. The true and perfect edition printed by the authors originall is sold by Richard Marriot under St. Dunstans Church in Fleet Street. That other nameless impression is a cheat and will but abuse the buyer as well as the author, whose Poem deserves to have faln into better hands."

In 1661 Thomas Jones, a girdler, lived under this tavern.

The house was a Protestant one, and was frequented by Titus Oates. The Green Ribbon Club met here. The old house was taken down in 1799 for city improvements.

The Harrow, against Inner Temple Gate, next door west of the King's Head.

From 1624-1643 Izaak Walton lived next door west to this sign. From 1671-1695 Thomas Dring, a bookseller, kept shop here. His house is sometimes called the Harrow and Crown.

No. 197, Rackstraw's Anatomical Juseurn.

No. 201, The Cock Tavern, ${ }^{1}$ or Cock Alehouse, as it was first called. It was in existence early in the seventeenth century. The landlord closed the house in 1665 on account of the Plague. The proprietor issued a token in 1655 . Pepys frequently visited this house in company with Mrs. Pierce and Knipp. It was famous for its chops, steaks, kidneys, and stout. It was demclished about 1886 . The business of the tavern was transferred to The Cock a little east of the Temple.

- Widdle Temple Gate. In 1700 we find B. Tooke, in $172 \mathrm{~S}$ Robert Gosling, in 1737 F. Cogan, and B. Motte and C. Bathurst, all booksellers, had shops here. Down the lane on the left is an old house anciently known as the Post House at Middle Temple Gate. In 1691 Collins, a bookseller, was at this sign. 1696-1712 Egbert Sanger, bookseller, was there. Now it is the shop of Abram and Sons,

1 The Institute is indebted to Mr. Philip Forman, F.S.A., for the loan of the drawing from which the accompanying illustration is taken. 
law stationers and printers, who have been there over a century.

Golden Serpent, near the Temple Gate. In $1660 \mathrm{~W}$. Dacres.

The Goat, near the Temple Gate, was, in 1684, the shop of Thomas Thorpe, goldsmith; in 1696, of Thomas Hussey, haberdasher of hats.

The following signs are described as being between the Temple Gates :-

Bible and Heart. 1686, Samuel Waisals, bookseller.

Fleece Tavern, 1688-1725.

Gay s Ilead. 1737, G. Anderson, bookseller.

Half Moon. 1723-1737, Thomas Woodward, book seller.

Locke's Ilead. 1718, T. Peele, bookseller.

Milton's Head. 1737-1760, George Hawkins, bookseller.

Roebuck. 1703, Robert Gibson, printer and bookseller.

Ship. 1734, C. Ward and R. Chandler, booksellers.

King's Head. 1696, John Story, hosier.

Temple Tavern. 1683-1695, John Viles.

Temple Exchange, near the Temple Gates. The following notice appeared in the Post Boy of August 31, 1695 :"In the Temple Exchange are shops and a lodging room appropriated to each shop. Rent free for half a year, fit for all such trades as are in other exchanges, and at the end of the said half year they are at liberty to quit the said place, if they do not find sufficient encouragement to pay a reasonable rent for the same. There has been some dispute at law, concerning it, which has hindered the Letting, but now all parties are agreed, and without doubt those that do enter therein may in a little time gain sufficiently, being situated in one of the best places of Trade in London near the Temple Gate in Fleet Street by Temple Bar. Enquire of Mr. Ongley at the Black Bull in Cornhill."

Temple Change Coffee House. In 1686-1696 auctions took place here.

Inner Temple Gate. Under this gate, in 1737, Jacob Robinson, bookseller, kept shop.

Fountain Tavern, Inner Temple Gate, down the passage. 1665, Monsieur Angiers advertises his famous remedies 
for stopping the plague ; to be had at Mr. Drinkwaters at The Fountain. The sign was also mentioned in 1702 .

The Pestle and Mlortar, at the Inner Temple Gate. 1685, Mr. Winn. A farthing token was issued of this house.

Star Tavern, next the Inner Temple Gate, in 1686.

Golden Key, next the Inner Temple Gate. In 1660 we find a man called Lambert there, who advertised for a white hawk that was lost. In 1677 William Boutel, bookseller ; 1686, Christopher Coningsby, bookseller. In 1690 it was a cutler's shop ; 1692, Thomas Hamersley, a linen draper ; 1699, Thomas Johnson, hosier ; from 1699 to 1737, Thomas Gamull, haberdasher of hats. During the same time, in 1711, we find Hammond Banks, a bookseller; and in 1710 Benjamin Fleming, goldsmith, here; and from 1731-1792 James Crokat, bookseller, kept shop.

T'emple. George Marriott, bookseller, was here in 1675, and Thomas Salusbury, bookseller, in 1689. In 1691 Peter Buck, at the sign of the Temple, near Inner Temple Gate, printed a new comedy called the Old Batchelor, by Mr. Congreve.

Judges Head. near Inner Temple Gate. Jacob Tonson, bookseller, came here from the Judge's Ilead, Chancery Lane. He published Dryden's works, and was secretary of the Kit-Kat Club. He was here from 1682-1698.

The following signs are met with as being over against St. Dunstan's Church :-

Black Horse. 1702, Samuel Cruwys.

Bible and Dial, sometimes called the Dial and Bible. In 1709 Edmund Curll, the bookseller, came here from the Peacock, Without Temple Bar. Curll was fined by the King's Bench for selling obscene books, whipped and tossed in a blanket or rug by the Westminster scholars, and put in the piilory at Charing Cross.

Crown and Sceptre. 1708, Robert Vincent, senr. and junr., booksellers.

Diall and Two Crowns. 1699-1709, Mrs. Cole, toyshop. She advertised wonderful medicines in the Tatler.

The Globe. 1736, John Senex, globe maker.

Golden Anchor. 1671, Ambrose Istead, and in 1690 W. Broome, a scrivener.

Hand and Sceptre. 1682, Robert Kettlewell, bookseller. 
Ilomer's Head. From 1696 to 1731 Lawton Gilliver, bookseller, was here. He published the first correct edition of Pope's Dunciad in 1729. The following note I extract from the Grubb Street Journal, 1731: "We are glad to hear, that in the controversy between those two eminent booksellers, Lawton Gilliver and John Sillycur, the former (a person of uncommon assurance, who has always shewn a particular enmity against our Society) has at last met with his match. And we have just now received the agreeable news, that he was this very evening rebaptised by the other, who gave him his own name. But as he did it only with the ceremony of sprinkling, which is but modern in comparison of the more ancient one of dipping, we hope he will with greater solemnity perform this upon him at Fleet Ditch, and dip him as much over head and ears, as we are informed he has been dipped himself."

$1760, \mathrm{~W}$. Owen, the mineral water man, was here. In 1772 C. Say printed the Gazetteer and New Daily Advertiser from this sign.

Judge Cokès Ilead. 1728-1737, T. Worrall, a bookseller. Maidenhead. 1679,

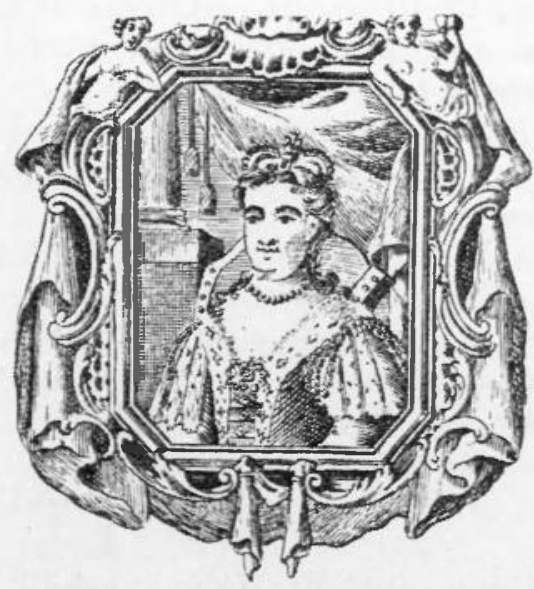

From the bill-head of Carr, Ibbetsons, and Bigge, at the Queen's Head on Iudgate Hill. $175 \%$. William Rogers, bookseller ; 1683-8, Timothy Goodwin, bookseller ; 1705, Francis Pryor, linen draper.

Queen's Head. In 1674 John Skerry advertisel for a swarthy man who went away from his friends being melancholy distracted! Thomas Cotton, a linen draper, was here in 1682. From 1694-1708 Timothy Goodwin, the bookseller, was here.

Seven Stars, orer against St. Dunstan's. John Field, a law bookseller, was here in 1658. In 1672 Robert Markham issued a penny token. Mrs. Markham's toy 
shop under St. Dunstan's Church (since Mrs. Cole left off shopkeeping) sells incomparable drops for the Palsey. (London Journal, March 22, 1728). She was also there in 1737 ; then Edward Withers, bookseller, was there from 1737-1742.

Three Flouer de Luces and Black Boy, orer against St. Dunstan's. 1678-1683, George Dring, a bookseller, was here. In 1718 the proprietor makes and sells all sorts of Ladies neat white and black Hats for riding or otherwise. (This was on the site of Hoare's Bank.)

In 1719 there was a hatter of the name of Huxley at the Black Boy, and shortly after we find, by the deeds in the possession of Messrs. Hoares, that the Widow Huxley, also a hatter in 1727, was at the Three Flouer de Luces. She probably continued the business at the latter sign, gave up the Black Boy, and called her house the Three Flower de Luces and Black Boy.

Three Pidgeons. 1710, C. Edgerton, haberdasher of small wares.

White Hart. In 1539, Richard Banks printed there for Richard Tavener. He had a Patent for Printing the Gospel, \&c. Here, in 1600 , was printed, for Thomas Fisher, the first edition of Shakespeare's Midsummer's Night Dream, a copy of which was sold at George Daniel's sale in 1864 for 230 guineas. From 1671-1683 John Wickens, publisher, and 1686, James Redditch, haberdasher of hats.

Turk's Head, Golden Turk's Head, and Great Turk's Head, interchangeable signs for the same house. In 1654-1665 William Lee published in English that unparalleled work written in Latin by the illustrious Hugo Grotius. From 1683-1713 Samuel Keble, bookseller, kept shop here. He published some of the Parliamentary Blue books. Christopher Coningsby appears at this sign from the Golden Key in 1692.

Flying Horse, Mitre Court, 1686.

Saddle Royal, near Mitre Court. 1735, Gooding, a saddler.

Over against Fetter Lane were the From the bill-head of following signs :-

Three Sugar Loaves. 1684, William Wright, confectioner.

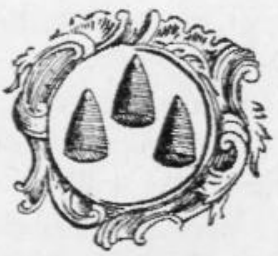

Wilson and Thornhill at the Three Sugar Loares, at the west end of St. Paul's. 1758. 
Red Cow, 1699.

Peacock. Roger Clavill, bookseller, lived there, and published Notes on Dryden's Virgil, by Milbourne. From 1675-1692 John Amery. He published the History of Appian of Alexandria. 1694-1698, Thomas Leigh, a bookseller; and in 1699 Henry Wills, haberdasher of hats.

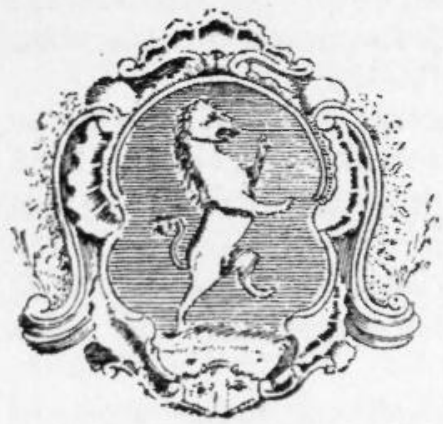

From the bill-head of Thomas Brom. wick, at the Golden Lyon on Ludgate Hill. 1756.

Golden Lyon. In 1674 this house was occupied by Michael Scrimpshaw or Scrimpshire. In the Little London Directory of 1677 he was keeping running cashes at this sign. He was a bankrupt in 1689. After which we find the names of the following goldsmiths: In 1691, R. Iacson; 1695, Marmion ; 1700, Samuel Wragg; and in 1737 a printseller named J. Tinney.

Crown and Mitre or Mitre and Crown. From 1709-1737, R. Gosling, bookseller ; after which we find Edward Littleton there.

Dolphin Tavern. In 1618 its host, Timothy Howe, was being continually presented, for keepinge their tobacco shoppes open all nighte and fyers in the same without any chimney and uttering hott water and selling ale without license to the great disquietude terror and annoyance of that neighbourhood. In 1630 he and another were presented for annoyinge the Judges of Serjeants inne with the stench and smell of their tobacco. (Noble's Memorials of Temple Bar.)

Ram Alley, now Hare Court, was at one time a sanctuary.

Ram Tavern. 1651, Ram Alley.

Sugar Loaf' or Sharge Lofe. The proprietor issued a farthing token.

Dyal, near Serjeant's Inn. 1676, Benjamin Shirley, bookseller; 1683-1693, Joseph Knibb, clockmaker. He remored to Suffolk Street.

Unicorne, near Serjeant's Inn. 1658, Baldron, haberdasher. William Warde issued a penny token after the 
Great Fire, 1666, before which he lived in Green's Rents, Fleet Bridge (see Boyne). From 1674-1699 John Shaler, a goldsmith, was here, and in $\mathbf{1 6 8 5}$ an apothecary named Weeks.

Harp and Feathers, at the corner of White Fryers, Great Gate. It was probably an inn. An advertisement appeared in the Gazette in 1679 that Robert Smith, a painter, was missing. Any news of him was to be given to his wife at this sign.

Two White Fryars, joining the Gate. In $1730 \mathrm{Mr}$. Saunders, Face Painter with Crayons, removed from Bath: now lives at W. Griggson's at this sign.

Lamb, near White Friars Gateway. In 1674 Barnes, haberdasher of hats; 1698 , Dent, a shoemaker.

Hat and Feather, next White Friars Gate. 1698-1i12, Mr. Parson.

Hog in Armour, Hanging Sword Court, now Whitefriars Street. 1677 John Young dealt in Sea Coal Sutt ! (sic.)

Faulcon, over against Horn Tavern. 1661, Mr. Wamseley, Falconer at the Faulcon, announced in Mercurius Politicus that he had lost a young Rammage falcon.

Crown Tavern, near Water Lane, 1682. The Court of the Fishery Office met here in 1716 .

Feathers, near Salisbury Court. In 1731 Mrs. Hills, child's coatseller, advertised her Anodyne Necklace in the Craftsman as a panacea against various complaints.

George, near Salisbury Court. George Bowers, a goldsmith, was here between 1678-1688. He struck a medal of the Protestant Martyr, Sir Edmondsbury Godfrey, whose body was found at the back of Primrose Hill, supposed to have been murdered in 1678. In 1682 he advertised several fine medals of the King and Queen and the Duke and Duchess of York.

Orrery and Globe, near Salisbury Court. 1732, Thomas Wright, mathematical instrument maker to His Majesty.

Gold Ring or Ring, near Salisbury Court. Edward Amson, a goldsmith, 1705-1720.

The following signs occurred opposite the Castle Tavern, or a little below the Conduit:-

The Griffin, opposite Castle Tavern, in 1556-8, was 
occupied by William Griffith, a bookseller, who printed at the Falcon, near St. Dunstan's.

In $1663 \mathrm{Mr}$. Waine advertised from the Griffon $\mathrm{Head}$, near the Conduit, which may possibly have been the same house.

Anchor, opposite the Castle Tavern. In 1690 we find Mrs. Eady there, and in 1694 it was the shop of Robert Cole, a goldsmith.

Black Swan, over against Horn Tavern. Charles Smith, bookseller, in 1673 .

Castle, opposite the Conduit and Castle Tavern.- 1593, Roger Warde, a printer, dwelt there, and in 1650 we find the names of John Martin and Jo. Ridley, booksellers. Baker, a silkman, was here in 1677.

The Sun, over against the Conduit, was in the occupation of several printers at an early date, so we may presume that the house changed its sign afterwards. In 1502 Wynkyn de Worde, the celebrated printer, printed The Ordynarye of Crysten Men in quarto "in the flete strete sygne of the sonne"; in 1530 he was at the same sign, described as being agaynste the Condyte. He died 1534. John Byddell, or Salisbury, was de Worde's Executor. He came here from Our Ladye of Pitye after de Worde's death. 1537-1556, John Wayland, printer and bookseller; 1549, William Baldwin; 1538-1560, Edward Whitchurch, printers.

Bear Tavern, 1681, near Bride Lane.

Le Bell Savage, otherwise le Bell Savoy. 1555, John Craythorne lived there.

Cup and Star, near Bride Lane. In $1718 \mathrm{Mr}$. Reynolds, a goldsmith.

Star, corner of Bride Lane. 1681, Mr. Reddish; and from 1691-1711 Henry Rhodes, bookseller, were there.

Topfeldes In, Parish of St. Brigid, in 1380 was the house of John de Chichestre, goldsmith, who bequeathed this tenement to his son William.

The following five signs were on Fleet Bridge, which connected Ludgate Hill with Fleet Street. It was taken down 1765, and the Fleet Ditch was arched over :-

Three Bibles, 1665, William Crook, bookseller.

Red Bull, 1665, Okeover lost a black gelding. In 
1684 it was called the Red Bull Head Tavern, Stephen Sedgewick being the landlord.

Rose Tavern, 1669.

Queen s Head. 1675, Robert Fowle, goldsmith, was here.

White Horse. In 1690 Thomas Issod, a goldsmith, was at this sign.

Rose and Fan, corner of Fleet Bridge. 1756, Todd and Lambden, glass and china men.

Our Ladye of Pity, next Flete Bridge. 1533, John Byddell, alias Salisbury, a printer. He afterwards went to the Sun.

Naked Boy, near Fleet Bridge. From 1664-1717 we find James Heriot, a goldsmith, brother german of George Heriot, of Edinburgh celebrity, keeping running cashes at this sign.

Black Horse, near Fleet Bridge. Stephen Walpool, an apothecary, was there in 1663 , and in 1742 James Crokatt.

White Bear, near Fleet Bridge, was spoken of in 1678, and in 1737 we learn the proprietor was the original maker of Feather'd Hats: hath now finish'd a fresh Parcel of curious Feather'd Hats and Pillarees in beautiful patterns, far exceeding anything of the kind that has been hitherto made.

Golden Press, by Fleet Bridge. 1541, Laurence Andrew, a native of Calais, was a printer here.

Golden Crosse, by Fleet Bridge. In 1539 we find the same man here, and that he produced a reprint of Caxton's Thymage or Mirrour of the Worlde.

Four Coffins, near Fleet Bridge. This was the sign of William Russell, a coffin maker. The following is his advertisement in the London Gazette August 18, 1684 :"William Russell, coffin maker, who hath the art of preserving Dead bodies without embowelling, sear clothing, cutting, mangling any part thereof and hath used it to the great satisfaction of all those honorable persons by whom he hath been employed, lives at the Four Coffins in Fleet Street. Coffins ready made and the bodies preserved for five pounds."

In November of the same year he advertised that he had been employed by the Earl of Carlisle to fetch over the body of Frederick Howard, Esq., who was slain in 
the sizge of Luxembourg, after it had been buried three months. He preserved it, and it lay in state at his shop and was buried in Westminster Abbey on the 11th of October last.

There was another undertaker at this sign called Stephen Roome, whose son was the unfortunate author whom Pope has gibbeted in the Dunciad as being afflicted with " a funereal frown."

Sir Edmondbury Godfreys Head, near Fleet Bridge, 1691, Langley Curtis, bookseller.

Black Mores Head, near Fleet Bridge. 1654, William Larner, bookseller.

Black Boy, near Fleet Bridge. 1691, Hastings Hyde.

Anderton's Coffee House, near Fleet Bridge, 1688--1695.

Seven Stars at Fleet Ditch. 1710, Ellis, goldsmith, advertised in the Tatler for a Necklace of French glass, with a runner of King Charles the First Head cut in amber and set in gold with a chrystal over it. In 1711 the name of Thomas Hines, brazier, appears.

Golden Ball, over against St. Bride's Lane. 1722-30, Mrs. M. Bartlet sold and made trusses.

Three Anchors or Three Golden Anchors, over against Salisbury Court, 1698. The trustees of the Land Bank removed here.

Cross Keys, below Fleet Conduit, was, in 1660, the house of Major Alsop, a sword cutler; 1685-90, Francis Sedgwick, goldsmith ; 1694, Thomas Heath, a silkman, and, in 1703, Hammersley, a linen draper.

Black Oliphant [i.e., Elephant], a little above the Conduit. In 1571 Henry Wykes printed here, and, in 1582, H. Cocken, a bookseller.

Lucretia Romana, or Lucreece, near the Conduit, was the shop of Thomas Berthelet, the King's Printer, from 1528-1555; in 1556 Thomas Powell; 1557, Henry Wykes; and, in 1571, Ralph Newbery, a printer ; and was then called Lucreece.

Saynt John the Euangelyst, beneath the Conduit, west of Shoe Lane. From 1521-1527 John Boteler, a printer, was there ; 1540-1578, Thomas Colwell ; and, 1576-1582, Hugh Jackson, both also printers.

Duke of Marlborough's Head, by Shoe Lane. British Apollo, March 20,1710, advertises all sorts of wonders, 
monsters, dwarfs, \&c.: A Pecary much admired by the learned; a Posom from the West Indies, having a false belly to secure her young ones from any danger, she running up a tree and hanging by her tail till her enemies are gone.

At the Duke of Marlborough's Head, in the great room, is to be seen the famous Posture Master of Europe, who far exceeds the deceased Posture Masters Clark and Higgins : He extends his body into all deform'd shapes; makes his Hip and Shoulder bones meet together; lays his Head upon the Ground, and turns his body round twice or thrice, without stirring his face from the Place; stands upon one Leg, and extends the other in a perpendicular line half a yard above his head; and extends his Body from a Table, with his Head a Foot below his Heels, having nothing to balance his Body but his Feet. With several other Postures too tedious to mention. Likewise a child of about 9 years of age that shews such postures as never were seen performed by one of his age. Also the famous English Artist, who turns his Balls into living Birds and takes an empty Bag, which after being turned, trod, and stampt on, produces some Hundreds of Eggs, and at last a living Hen. Side Boxes 2/-, Pit 1/- To be performed at 6 a Clock every Evening. (Spectator, January $8,1712$.

Duke of Marlborougli's ITead. A managerie at the Duke of Marlborough's Head in Fleet St. is now to be seen a invented machine composed of 5 curious pictures, with moving figures, representing the history of the heathen gods, $\mathrm{w}^{\mathrm{ch}}$ move artificially as if living the like not seen before in Europe. The whole contains near 100 figures besides ships, Beasts, Fish, Fowle and other Embellishments some near a foot in height; all of which have their respective and peculiar motions, their very Heads, Legs, Arms, Hands and fingers Artificially moving to what they perform, setting one foot before another like living creatures in such a manner that nothing but nature it self can excel it. It will continue to be seen every day from 10 in the morns 'till 10 at night. The Prices $1^{s \cdot} / 6^{d}$, and the lowest $6^{d .}$ (The Spectator, September 27, 1711.)

Here, in 1718, De Hightrehight, the fire-eater, ate 2 c 2 
burning coals, swallowed flaming brimstone, and sucked a red-hot poker five times a day!

Dial, next the Castle Tavern, south-west corner of Shoe Lane. 1698, Martin, a watchmaker, lived here. In 1714 the business was conducted by George Etherington.

Castle Tavern was the south-west "corner of Shoe Lane. It was first mentioned in 1432. The Clockmakers' Company held its meetings here, before the Great Fire, as early as 1631, they having no Hall of their own. The proprietor issued a farthing token. In 1708 it boasted of the largest sign board in London.

White Lyon and Crown, near Wine Office Court. 1692, Mrs. Lees, a milliner.

Fiaven, near Wine Office Court. George Ferne, seedsman and netmaker, called the original seed and net warehouse, was here from 1756-1764.

White Hart, over against Water Lane. 1694, Mrs. Clarke, a milliner.

Printing Press, against Water Lane, where I. Mayo printed and sold the paper called The British Apollo in 1711.

Ilen and Chickens, over against Water Lane. 1686, Nathaniel Turner, linen draper.

Grocers' Company's Arms, next door to Hinde Court. Thomas Cordin issued a halfpenny token (see Boyne).

Mr. Barnebies Antipestilential Yowder which he received from the author of it, Dr. Whitaker, to be burnt into a fume, being already approved upon tryal by several attestations to be of singular effect; is to be sold by Mr. Cordwin next door to Hinde Court, Fleet Street.

(The Intelligencer, No. 61, August 7, 1665.)

In 1675 Maydwell, an oilman, was here.

Falcon, between Bolt Court and the Conduit. 1660, George Sedley, a saddler of the Livery. In 1676 he advertised seeds.

Three Kings, opposite Bolt and Tuu. In 1662 an advertisement appeared in the Mercurius Publicus concerning a lordship that was to be sold. Further particulars were to be had within. In 1664 John Ashton issued a farthing token.

Dial and One Crown, opposite Bolt and Tun. Thomas 
Madge, the watchmaker, was here about 1752. He made Dr. Johnson's first watch in 1768 .

George, Red Iyon Court. 1678, Robert Petit.

Castle Tavern, corner of Fetter Lane. This is the second of the name. In 1717 it was kept by Mrs. Shackleton.

King's Arms, next the Leg Tavern, which was at the corner of Two Cranes Court. In 1737 a bookseller, name J. Mechell, kept shop there. The following is his curious advertisement which appeared in the London Erening Post:-

\section{"Next Saturday will be published,}

"The Alchymist; or, Weekly Laboratory ; in which, by the Secrets of the Hermetick Art, will be made an exact Analysis of the different Principles which compose those Sorts of Mixts, call'd Weekly (and other) Papers. The several Letters of which will be put into the Alembick, in order to draw from them the Phlegm figur'd by the Velleities which may be contain'd therein. The Spirit will be metaphorically represented by the Solidity and Strength of Reasoning, as well as Proof; the Oil by the Elegancy and Beauty of the Stile: the Sal Volatile, by the Brightness and Subtilty of its Points; and lastly, the Caput Mortuum, by the Nonsense, Contradictions, Incoherences, \&c.

"Foreign and Domestic News will also be put to the Crucible, to purge them of those Heterogeneous Bodies which frequently disguise them, insomuch that it becomes alınost impossible for the Reader to discorer the real and genuine Substance.

"Religion itself will not escape the Hands of the Artist, it being his Design to put it pretty often to the Coppel, to free it, if possible, from those Impurities it may have gather'd in passing thro' the various Matrixes since its first Institution.

"N.B. He will likewise be provided with Sublimatory Vessels, thro' which will pass the greatest Part of the Advertisements.

"Printed by J. Mechell, at the King's-Arms, next the Leg-Tavern in Fleet-street."

Leg Tavern, east end of Fetter Lane, corner of Two Cranes Court. 1712, Vr. Whitum, hosier. 
Ship, 1724, a watchmaker's.

King's Head, end of Fetter Lane. In 1685 John Wells, upholsterer; 1694, John Nowland, tobacconist, and, in 1721, Thomas Butler, a bookseller, was there.

Blackamoor, over against Serjeant's Inn. 1726: There is now preparing for the Press a History of the Irish Rebellion in 1641. Whoever has any papers relating to the subject of the History, it is hoped he will be so kind as to communicate them direct to the Editor.

The following are near St. Dunstan's Church:---

The Three Pattins, between Fetter Lane and St. Duustan's Church. 1692, Mr. Morrel.

Three Golden Balls, near St. Dunstan's Church. 1672, Mr. Townsend, a tobacconist.

Rose and Crown, corner of St. Dunstan's. 1711-1718, Mrs. Osborn, toy shop. She sold waters for the King's Evil.

Prince Eugene's Head.

Princes' Arms. 1556-1587, Thomas Marsh, printer and bookseller. He printed Stow's Chronicle. In 1587 he was succeeded by Henry Marshe.

Bull's Head Tavern. 1656, John Bryan issued a farthing token in 1667 (Boyne). 1683-7, Mr. Sedgewick.

Palm Tree. 1660, William Palmer, bookseller.

Kings' Arms, next the Church. In 1661 Philemon Stephens, a bookseller, was here, and, in 1692, another bookseller named Thomas Salisbury. Mr. Kenton, a goldsmith keeping running cashes, is described as being here in the Little London Directory, 1677. In 1712 we find a tea man kept the shop, and we read in the Post Boy that the very best coffee was sold here at $5 s$. $8 d$. the Pound, the very best Bohee Tea at 18s. the Pound and very good at $14 \mathrm{~s}$. the Pound. The very best green tea at $14 s$. the Pound and very good at $10 \mathrm{~s}$. the pound, \&c.

"Winpenny \& Co. at the King's Arms Office St. Dunstan's Church, beg leave to acquaint the public that they have still a supply of Museum Lottery tickets in a great variety of numbers, that the state of the wheel is now more in farour of the adventurers than the first day of drawing. N.B.-Tickets and shares in the State Lottery sold by receipt and all business regarding the same transacted with the utmost fidelity." (London Chronicle, June 10, 1775.) 
Golden Hart. 1696, Francis Clark, goldsmith. He was also described as of the Golden Buck.

Golden Ball, between the Church and Chancery Lane. 1675-78, Thomas Burrell, bookseller; 1729, I. Isted. He succeeded R. Crouch, also a bookseller; he sold Patent Medicines and advertised a cure for the stone.

Glass-Seller's' Arms, corner of the Church. 1737, Benjamin Payne, chinaman. He also sold tea.

Comb, first met with in 1709. Mr. Stephens sold an original Japan plaister for curing corns here in 1730 .

Artichoke, next to Church. 1685, W. Freeman, a bookseller; in 1719 it was the shop of Thomas Johnson, hosier.

Cock and Sugar Loaf. 1677-80, James Wade, a bookseller, was here; in 1678 Mrs. Matthews, a sempstress, lived here.

George, near Clifford's Inn. In 1493-1527 Richard Pynson, printer, was here; 1525-1547, William Middleton; 1529-1540, Robert Redman ; 1540, Elizabeth Pickering, formerly Redman; 1556, William Powell-all printers. In 1655 Thomas Dring was selling books at the George; 1662-1692, Thomas Bassett, bookseller. His apprentice, Jacob Tonson, lived here some time.

St. Dunstan s Coffee House, 1692-1700.

St. Dunstan's Parish. An account of an artful fraud called guinea dropping was written in the Post Boy, September 8, 1698.

Ink Bottle, Clifford's Inn Gate. Christopher Coningsby sold books here from 1702-9.

Clifford's Inn Coffee House. 1689-90: Tickets for the Yorkshire Feast, to be held at Merchant Taylors Hall on February 14, were sold here.

Globe and Sun, between St. Dunstan's and Chancery Lane. 1732, Richard Cushee, globe maker.

Flying Horse Court, near King's Head Tavern near Chancery Lane.

Flying Horse. Dan Major sold the Little London Directory here in 1677-9; John Gay published many ballads from this sign in 1680; George Purefoy, a haberdasher, was here from 1673-1686; and, in 1693, John Watts, a picture seller.

Golden Perriwig, corner of Chancery Lane. 
Jessamine Tree and Snuffing Gentleman, near the King's Head Tavern near Chancery Lane. In 1682 James Norcock sold all sorts of snuff.

Tobacco Roll, near Chancery Lane. 1678, Mrs. Howse, a grocer.

Daniel's C'offee House, between Chancery Lane and Temple Bar. Auctions took place there in 1737.

Golden Fleece, over against Inner Temple Gate. 1693, Richard Southby, bookseller.

Whyte Lyon, against the Temple. 1671, Thomas Dring, bookseller ; from 1679-1702, John Jackson, hosier.

City of Seville, over against Inner Temple Gate. 17051711, Dighton, Her Majesty's perfumer.

Queen's Head Tavern, over against Middle Temple Gate. Mr. Pierson, goldsmith. In 1691 he advertised for a green spleen stone which was lost to be brought to him here; he

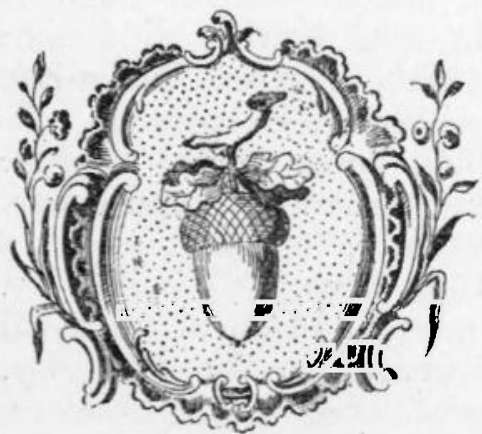

From the bill-head of William Garsed, haberdasher, at the Acorn on Ludgate Hill. 1760. lived next door.

Acorn. Richard Pierson was carrying on a goldsmith's trade here from 1672-1712. He was succeeded by Edward Pierson, who failed about 1730. In 1688 he is described as being at the $A$ corn, next door to the Queen s Head Tavern, over against the Temple.

Bell, over against Middle Temple Gate. Abel Roper, bookseller, in 1689, kept shop here, and, in 1671, Jo. Leigh, bookseller.

Bible, against Middle Temple Gate. 1674, Henry Million ; 1692-1709, William Freeman, bookseller.

Pheasant, Temple Bar. 1680, Mrs. Grace Bland.

Hand and Pen, near Temple Bar. 1691, Thomas Beaver, bookseller. seller.

Dryden's Head, Temple Bar. 1737, Warner, bookAngel, near Temple Bar. 1692, Parker, a goldsmith. Judye's Head, opposite Dick's. 1737, Thomas Worrall, bookseller. He removed from the Judge's Head, opposite to St. Dunstan's, to this Louse. 


\section{White Bear, Bell Yard, 1682.}

Horns and Harrow, Bell Yard. 1677, Lawrence.

Bell Inn, Bell Yard. 1672, David Bland.

Civet Cat, a few doors from Bell Yard. 1664, $\mathrm{Mr}$. Boadsworth was here, and advertised for a lost negro boy. In 1665 another advertisement appeared in the Intelligencer, May 1, to the effect that a negro boy with a cross on his forehead, about twelve years old, speaking Spanish indifferently well and English good, was lost; had been missing about a month. Application to be made to $\mathrm{Mr}$. Rowlett at this sign. 1696, Edmund Bolesworth advertised for a silver hilted sword and grey gelding!

Black Swan, near Temple Bar.

Three Tun Tavern, within Temple Bar. 1704, Abraham Isdell, vintner.

Three Golden Lions, near Temple Bar. 1695-1712, John Lund, a goldsmith.

Queen s Mead and Rose, near Temple Bar.

Trumpet, Sheer Lane or Shire Lane, near Temple Bar, 1696.

The following is a list of those signs which I have not been able to localise to any particular part of the street :-

Angel and Crown. From 1696-1714 John Jackson, is goldsmith, lived here, and probably before this date. He offered a reward in the Post Boy, February 12, 1713, for the apprehension of his runaway apprentice, and there described his house as being over against the Whitehorse Inn.

Bell and Ball. 1677, Thomas Savage, a woollen draper : 1685-1693, Purley, a woollen draper.

33ird in Hand. In 1665, in the Newes of April 2i, 166j, Ambrose Mead, a goldsmith, inserted the following :--A gold watch made by Benjamin Hill in black case studded with gold, with a double chain and the key on a single chain with a knob of steel upon it, was lost and notice was to be given to Mr. Mead at this sign.

Black Dog. 1675, James Gover, an apothecary. London Gazette, March 27, 1676 : " Lost from the Black Dog in Fleet Street a little spout silver tankard, a Cawdle cup, a cup with two ears, a little candlestick, a silver thimble, two money boxes \&c. with Three pounds five shillings in money and Linnen and laces \&c. Whoever 
gives notice that the things may be had again to the Black Dog in Fleet Street near Fetter Lane, shall have forty shillings reward." In 1698 J. Bradley called the sign the Derby Ale House.

Black Boy and Comb was a toy shop in 1721.

Black Spread Eagle. 1642, Alice Norton printed here for Humphry Tuckey or Tucker. In 1664 Tucker himself was here, and sold "Alexacarius or Spirits or Salts," prepared by Constantine Rodocares."

Blue Anchor. 1711, Thomas Burgess, a druggist.

Blew Bell. In $1678 \mathrm{~J}$. L, a printer of the following Broadside: "Proclamation promoted or an Hue and Cry and Inquisition after Treason and Blood: upon the inhumane and horrid murder of the noble Knight, Impartial Justice of the Peace and Zealous Protestant Sir Edmondberry Godfrey of Westminster. An Hasty Poem. O Murder! Murder! let this shriek fly around, Till Hills and Dales and Rocks and shores rebound."

Blew Boar. 1675, Thomas Rogers, upholsterer; 1691-6, Mr. Farmers.

Blue Garland. 1541, John Wayland, printer.

Blew Star. 1675, Thomas Rogers, upholsterer. This is a strange coincidence, as at the same date he was at the Blew Boar.

Book and Wheatsheaf. 1697, Richard Rooke.

Boyle's Head. 1735, John Whiston, bookseller.

Britannia Tavern. 1699.

Buck and Sun. (See Golden Buck, No. 53.)

Bunch of Grapes. 1714, Gregory, a silkman.

Cabinet. 1693, Thomas Heath, silkman.

Cowpe on the Hoope. This was a brewhouse belonging to the celebrated Sir William Sevenoaks, Lord Mayor of London, in 1418, who was a foundling of Sevenoaks.

Le Crane on the Hoop, St. Dunstan's Parish. 1435, Thomas Knolles, senior, grocer. This brewery he left to the Dean and Chapter of St. Paul's.

Crown and Dial, sometimes called the Crown or the Golden Crown, between 1676-1703 was occupied by Robert T. Halstead, a goldsmith.

Crown. Halstead (see ante).

Crown and Fox. 1692, John Reynolds, upholsterer.

Dial ana Mitre. 1710. 
Doy and Ball. 1703, Merrick, a distiller.

Diake. 1710 , Humphrys.

Eagle and Child. 1648.

Faulcon Coffee House. 1683.

Fleece. 1692, Richard Southey, bookseller.

Fig Tree. 1691, Henry Smith, grocer.

Five Bells Tavern. 1690, Mr. Lavender.

Fourdelys (Fleur de Lys), a tavern. 1396, John Walworth, vintner, bequeathed this leasehold tavern to Richard Jancox, charged with the maintenance of a conduit which the testator had erected in Fleet Street. (Cal. of Wills, Ct. of Husting.)

Fox and Crown. 1678, John Reynolds. He advertised for a runaway lad in the London Gazette, which is as follows: "A young man aged about 18 of a well set body, broad faced, short dark brown hair somewhat curling, his countenance smiling, legs large, with calves bending outwards, a stooping gate, toes bending inwards, a little limping in his feet, his cloaths of a sad colour, cloath new, went away from his Master the 8th Instant designing for Sea. His relations earnestly desire his return; Whoso can be assistant therein and send notice to John Reynolds at the Fox and Crown in Fleet Street, shall receive full satisfaction for their care and trouble."

Garden of St. Andrew's Cross on the Hoop. 1416.

Golden Snail. 1734, James Brooker.

Golden Sun. 1493-1534, Wynkyn de Worde, printer.

Golden Tun. 1594, Winnington, bookseller and publisher.

Grasshopper. 1699, Henry Smith, linen draper.

Grayhound Tavern. 1685, William Bold advertised for a Port Mantle, containing books and writings taken from the Oxford Arms Inn.

Hand and Plough. 1594, Mattes, bookseller and publisher.

Harry S Coffee House. 1740, Mr. Davies, the vintner, died at the age of 110 years.

Hat and Bever. 1677, William Ward, haberdasher of hats.

Helmet. 1692-7, Metcalfe, upholsterer.

Hurace's Head. White, the bookseller, lived here.

Horse Shoe and Star. 1815. 
Jerusalem. 1657, Andrew Grace issued a farthing token. King's Arms and Key. 1737, C. Mosley, engraver.

Kings and Keys Tavern. 1838. Probably an abbreviation for Three Kings and Cross Keys.

Lion. About 1660 a farthing token was issued of this house.

Lion's Head. Erected 1713.

The Lock and Key. Praise God Barebone was a leatherseller at this sign. He let his house to a man named Speight; it was destroyed in the Fire of London, and rebuilt.

Lord. Bacon's Head. 1756, L. Davis, bookseller.

Nag's Head. 1675, Mr. Warneford.

Naked Boy. 1689-1693, Samuel Newington, woollen draper.

Old Lute. 1676, Charles Lingwood.

Phonix, 1685 . In 1705 , Chorley, glass-seller.

Plough, a hatter's sign. On February 28, 165y-60, Pepys, with Will: Howe, went here to buy a hat.

Pope's Head. 16i8, Simon Lince, woollen draper.

Prince of Wales's Feathers. Thomas Tickner issued a farthing token about 1660 .

Red Cross. 1706, Preston Duncan, druggist.

Red Lyon, against the Greyhound Tavern. 1696, Mr. Terry, stationer.

Rook and Wheatsheaf. 1695, Richard Rooke.

Rose, near the Globe Tavern. 1763, S. Garraway, seedsman.

Rose Garland. 1508-1547, Robert Copland, printer, an assistant of Caxton ; 1553-1569, William Copland, bookseller and printer. Juliana Berner's Booke of Hawking, Munting and Fyshing was printed by him.

Saracen's Head. 1675, Roger Williams, draper.

Shakespeare's Head. 1760, J. Curtis, bookseller. here.

Sheffield's Coffee House. 1700, book auctions were held

Snail. 1721, Watts, a goldsmith.

Sun Tavern (between Fetter Lane and Shoe Lane). Lewis Willson issued a halfpenny token; he was here from 1661-1665.

Swan Tavern, 1687.

Three Bells. 1732, Richard Bristow, a goldsmith, adver- 
tised that he sold and delivered Bristol, Pancras and Bath water to any part of the town.

Three Crouns. 1687, Thomas Fownes ; 1720, Ed. Fazakerley, linen draper.

Three Hats. The proprietor issued a token in 1665 .

Three Nuns. John Harward issued a farthing token.

Turk's Head. 1698, Brodrapp, haberdasher of hats.

Two Kings and Key. 1694.

Whale. 1705, Charles Whaley, druggist. He also sold chocolate.

Whitehorse. 1719, Thomas Burgess and Seth Lofthouse, goldsmiths.

Whitehorse and Bell. 1729, John Waler, brazier and ironmonger. He removed to the same sign in Cheapside. He invented a clock lamp. (See picture of sign in Craftsman, October 11, 1729.)

Whitehorse Inn. 1685-1691. Thomas Mahew advertised this house to be let in 1691 . In 1711 we read there was a very good coach to be sold a Pennyworth; enquire within. The Blandford Flying coach started from here in 1742 , and took two days to do the journey.

Having now exhausted my store of the Fleet Street signs, it only remains for me to thank you for the patience you have evinced in listening to this somewhat lengthy paper, which has given me much pleasure to prepare. The history of many of the houses has been necessarily curtailed, as they have been more fully described elsewhere by various authors, myself amongst the number. It will be seen from this what a favourite street this has always been for the printer and bookseller, there having been a preponderating majority of them over all other trades, and, as far as the former is concerned, exists at the present day, as I presume there are more printing presses in Fleet Street and its neighbourhood than in any other part of the Metropolis. 